\title{
SYSTEMIC INDICATORS OF ROAD INFRASTRUCTURE AT ACCIDENT CLUSTERS
}

\author{
Elena Kurakina¹, Sergei Evtiukov², Grigory Ginzburg ${ }^{3}$ \\ 1,2Saint Petersburg State University of Architecture and Civil Engineering \\ Vtoraja Krasnoarmeyskaya st., 4, Saint Petersburg, Russia \\ ${ }^{3}$ International Association of Accident Reconstruction Specialists \\ United States of America \\ ${ }^{1}$ Corresponding author: elvl_86@mail.ru
}

\begin{abstract}
Introduction: To study road infrastructure and ensure control over its changes during its use, it is required to introduce a concept of indicator, which is a parameter or characteristic of road infrastructure facilities' state. Studies on road infrastructure indicators are aimed at traffic safety increase, improvement of a system for road accident forecasting. The authors apply a system for the accounting of road infrastructure facilities' characteristics, set during the design and construction of roads, to forecast road accidents. Purpose of the study: The authors develop an approach to studying the influence of systemic indicators of road infrastructure at accident clusters on traffic safety. Methods: During the study, such methods as system analysis, extrapolation method, method of forecasting with account for seasonality, and method of repetition were used. Results: The authors analyzed statistical data on the road accident rate and identified significant systemic indicators of road infrastructure to assess the efficiency of road and construction measures aimed at traffic safety assurance. They formed groups of indicators in the system of their parametric characteristics and determined conditions of their use to study systemic indicators of road infrastructure. They also determined the capabilities of methods used to forecast the road accident rate to develop an algorithm to analyze road infrastructure at accident clusters. The authors also developed such an algorithm to analyze road infrastructure at accident clusters.
\end{abstract}

Keywords
Road, indicator, road surface, vehicle, road accident, accident cluster.

\section{Introduction}

A system of indicators reflects changes in road infrastructure characteristics set during the design and construction of roads. The system is aimed to detect and prevent violations at various stages of the entire life cycle of a road. Non-compliance with the requirements of technical standards during the design, construction, operation, reconstruction, and maintenance of roads results in the impairment of Driver-Vehicle-Road-Environment (DVRE) system serviceability. In particular, it can lead to the premature destruction of the road surface or formation of defects in it, deterioration in road surface performance affecting its adhesion properties, poor condition of the roadway and shoulders (especially in winter). These factors cause accident-prone situations, decrease traffic safety and increase the number of road accidents. In other words, it is obvious that the Road component of the DRVE system is important in the assurance of traffic safety. It is also confirmed by the start of the "Safe and High-Quality Roads" national project in December 2018 (expected to end in 2024), which includes such plans as Road Network, System-Wide Measures of Road Industry Development, and Traffic Safety. Within the system of traffic safety assurance, various methods are used to solve its functional tasks: forecasting situations in the DVRE system, identifying factors and causes of road accidents, choosing efficient measures intended to increase traffic safety, etc. In this regard, the contribution of the following researchers shall be mentioned: Silyanov V. V. (Moscow Automobile and Road Construction State Technical University (MADI), Moscow); Domke E. R. (Penza State University of Architecture and Civil Engineering, Penza); Brannolte U. (Germany); Pribyl P. (Czech Republic); Kapsky D. V., Kot Ye. N., Vrubel Yu. A. (Belarusian National Technical University, Belarus); St. Petersburg researchers such as Kravchenko P. A., Dobromirov V. N., Evtyukov S. A., Vasiliev Ya. V., Grushetsky S. M., Plotnikov A. M. (Saint Petersburg State University of Architecture and Civil Engineering, Saint Petersburg). They gave 
significant attention to studies on the Road component and published numerous papers on the matter that included:

- results of studying the transport and operating conditions of roads, including the determination of a dynamic pattern in braking and adhesion characteristics of vehicle wheels on the road surface at the stage of road operation and reconstruction (Brannolte et al., 2017; Domke and Zhetskova, 2011);

- modeling of the mortality rate as a result of road accidents, considering the road factor and with regard to roads of regional significance (Vrubel et al., 2006);

- results of studies aimed at reducing the number of jams and controlling the capacity of highways with account for the geometry of roads (Domke and Zhetskova, 2011);

- results of studies on transport and pedestrian traffic management. Some researchers laid the groundwork for the use of special traffic lights increasing the efficiency of coordinated traffic management (Evtiukov et al., 2017; Kravchenko, 2013);

- method of road accident reconstruction with account for the technical condition of a vehicle and road environment; results of analyzing accident clusters with the development of efficient traffic safety measures (Kravchenko and Oleshchenko, 2017; Kurakina, 2018; Kurakina et al., 2018; Rajczyk et al., 2018).

The conducted studies were, to an extent, of local nature. Their results do not provide any tools to perform a comprehensive qualitative evaluation with regard to the influence of the road / road infrastructure / road environment state on the appearance and development of prerequisites to the emergence of accident clusters. The analysis of the results provided by the researchers mentioned above confirms that it is necessary to apply an integrated approach to the use of systemic indicators of road infrastructure to determine causes, factors and risk metrics of road accidents, and detect accident clusters. Along with that, it is required to improve methods of road accident forecasting, such as methods of conflict situations and potential dangers, extrapolation, forecasting with account for seasonality, and repetition to prevent or rule out the emergence of accident clusters. Databases on the state of road infrastructure facilities, developed during the design and construction of roads, play an important role in the implementation of these methods.

Due to the evaluation of the actual accident cluster state, it is possible to assess road infrastructure, its safety, and potential accident risk (Evtyukov and Vasiliev, 2008). Based on identified deficiencies and cases of noncompliance with regulatory documents, we can assess the compliance of roads with rules and regulations with account for the relief and climate of the district at the stage of their operation. At the stage of evaluation, the analysis of qualitative and quantitative characteristics of the traffic flow, vehicle braking, and road pavement durability in terms of modulus of elasticity played an important role (Kurakina et al., 2017).

Due to the analysis and processing of data obtained using diagnostic methods, it is possible to determine if the actual state of road infrastructure meets regulatory requirements. Road infrastructure indicators based on such a study allow us to develop measures aimed at the elimination of black spots, accident rate decrease, increase in the reliability of conclusions and accuracy of calculations when carrying out expert examination following road accident reconstruction (Federal Road Agency (Rosavtodor), 2015; llarionov, 1989).

\section{Subject, tasks, and methods}

The subject of the study is road infrastructure indicators affecting traffic safety assurance.

The tasks of the study are as follows:

- to assess the possibility of using traditional methods of road accident rate forecasting to develop an algorithm to analyze road infrastructure at accident clusters;

- to analyze statistical data on the road accident rate and provide a rationale for systemic indicators of road infrastructure to assess the efficiency of the proposed road and construction measures aimed at reducing the number of road accidents;

- to form a group of indicators for the system of facilities' parametric characteristics and provide a rationale for the conditions of their use to analyze road infrastructure at accident clusters.

To solve the tasks set, the authors used methods of conflict situations and potential dangers, system analysis, extrapolation, forecasting with account for seasonality, and repetition to prevent or rule out the emergence of accident clusters. They also used software-based computational methods, methods of the probability theory, methods or results' processing, and information technologies.

\section{Results and discussion}

To analyze the accident rate, the authors used statistical data on the number of road accidents, including accidents with injuries and fatalities. The results of the analysis (with the Leningrad Region as an example) are given in Figures 1 and 2. They show that up to $25 \%$ of all road accidents are caused by the poor condition of roads (including up to $26 \%$ with injuries and up to $29 \%$ with fatalities).

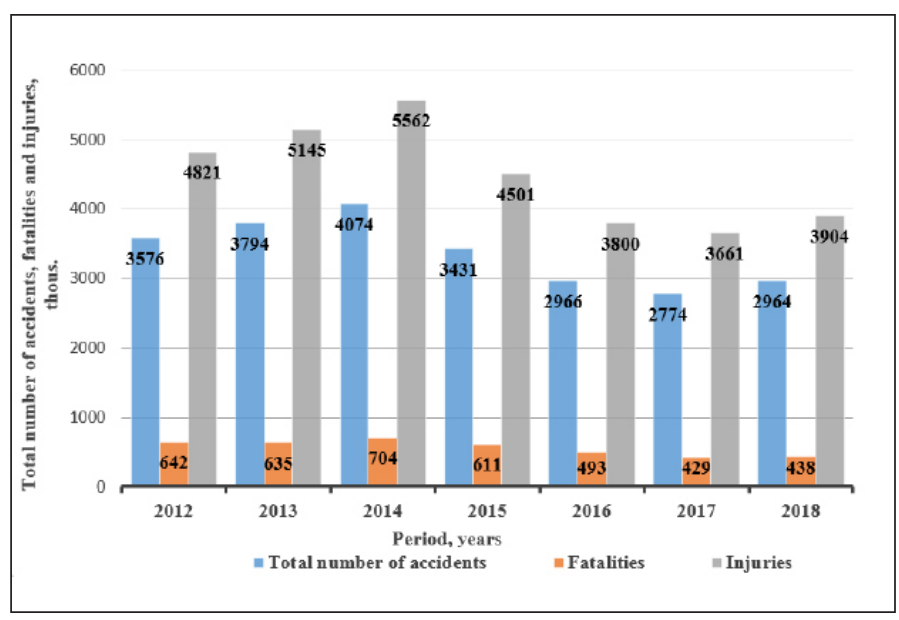

Figure 1. Accident rate on regional public roads in the Leningrad Region during 2012-2018 


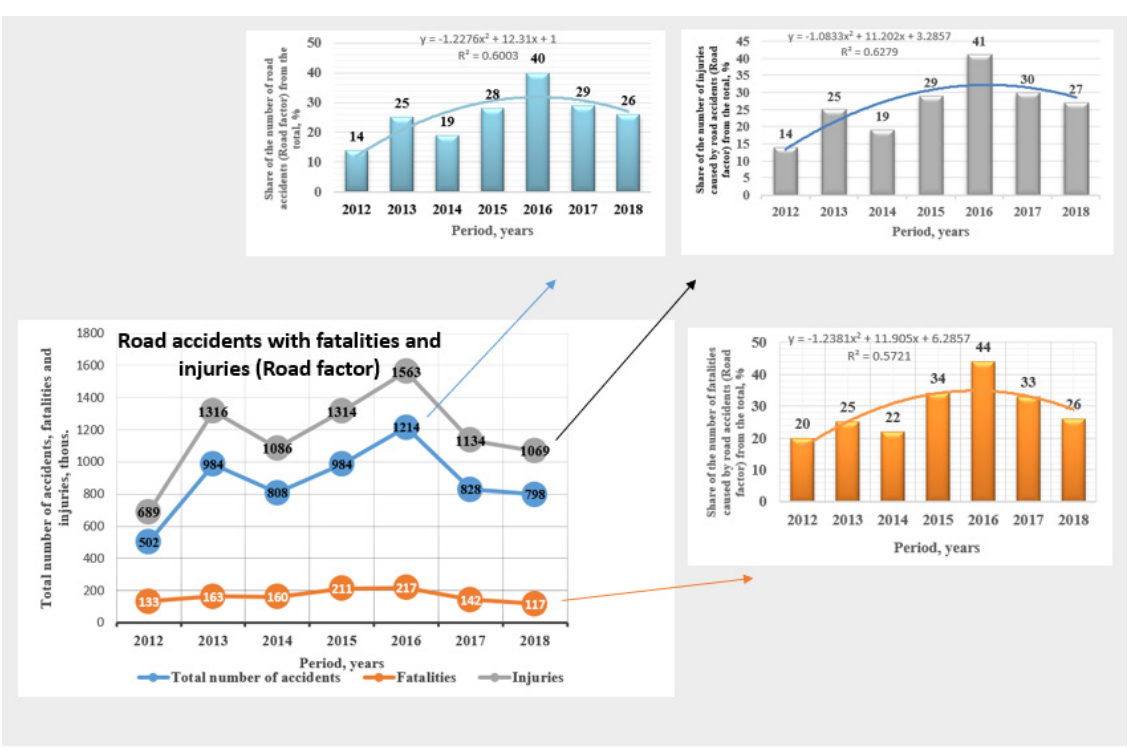

Figure 2. Trend changes in road accidents (with killed and injured persons) due to the poor condition of roads in the Leningrad Region from January 2012 to December 2018, \%

The polynomial trend changes in road accidents (with killed and injured persons) regarding the Road factor (Figure 2) allow us to forecast the accident rate on roads. To minimize the contribution of the Road factor in the emergence of road accidents, a system of road infrastructure indicators is required. By monitoring such indicators, it is possible to forecast prerequisites for road accidents. For that purpose, various analytical methods of assessing traffic safety in road infrastructure can be used (Kapitanov et al., 2018; Plotnikov, 2016; Suvorov et al., 1990).

Table 1. Analytical methods of traffic safety assessment

\begin{tabular}{|c|c|c|c|}
\hline No. & Method & Characterizing parameters & Studied parameters \\
\hline 1 & Safety factor method & $\begin{array}{l}\text { Maximum traffic speed at the } \\
\text { analyzed road segment - } \\
V_{\text {max }}^{T F} \\
\text { vehicle's initial speed - } \\
V_{\text {init }} .\end{array}$ & $\begin{array}{l}\text { Traffic intensity. Shoulder-to-shoulder } \\
\text { width and width of shoulders. Clear } \\
\text { vision distance (plan and profile views). } \\
\text { Longitudinal grade. Curve radius in the } \\
\text { road cross-section (on long ascending } \\
\text { grades) }\end{array}$ \\
\hline 2 & Accident rate factor method & $\begin{array}{l}\text { Partial accident rate factors }-K_{i} \\
\text { The final accident rate }- \\
K_{a c c}-\text { depends on the number of } \\
K_{i} \text { obtained from the analyzed site }\end{array}$ & $\begin{array}{l}\text { Results of road accident statistical } \\
\text { analysis. Traffic intensity. Shoulder-to- } \\
\text { shoulder width and width of shoulders. } \\
\text { Number of traffic lanes. Clear vision } \\
\text { distance (plan and profile views). } \\
\text { Longitudinal grade. Clear vision (plan } \\
\text { and profile views). Vertical curves (plan } \\
\text { view). Grade separation. Road surface } \\
\text { condition (Federal Road Agency } \\
\text { (Rosavtodor), 2015; llarionov, 1989). }\end{array}$ \\
\hline 3 & Black spot identification method & $\begin{array}{l}\text { Absolute and relative number of } \\
\text { road accidents }\end{array}$ & $\begin{array}{l}\text { Traffic intensity. Results regarding road } \\
\text { accidents with injuries. }\end{array}$ \\
\hline
\end{tabular}

During traffic safety assessment using analytical methods, only a few parameters are studied, which compromises the quality of evaluating causes of accident clusters' emergence and accident rate forecasting.

In the course of forecasting, it is possible to apply mathematical methods to evaluate changes in the accident rate on roads. It has been established that it is reasonable to apply the extrapolation method only in the case of shortterm accident rate forecasting. The method is applied based on a statistical data array regarding the number of persons killed and injured in road accidents for at least three years. Extrapolation is performed for the subsequent period. When processing extrapolation results, we determine the level of significance indicating the probability of erroneous conclusion. The level of significance ( $\alpha$ ) may differ for actual and estimated data. Such a situation points to the fact that extrapolation is not suitable for forecasting. The method of forecasting with account for seasonality is 
based on an assumption that the number of road accidents depends on the season. When this method is applied, data for at least one year (by months) are used to evaluate the road accident dynamics. However, this method cannot provide a qualitative assessment of the accident rate since the analysis lacks additional data on the state of the road and road environment. The method of repetition is based on the forecasting and changing of one parameter used to analyze statistical data (e.g. the number of road accidents per day). If during the calculation of the level of significance $\alpha$, actual and estimated values differ, this suggests that the situation analyzed is not described to the fullest extent possible. Therefore, when applying traditional methods of forecasting, it is possible to face the following disadvantages:

- high calculation error;

- inapplicability of some individual results to generate a general forecast;

- insufficient number of indicators, characterizing the state of the road and road environment, taken into consideration (Suvorov et al., 1990).

Therefore, to obtain more accurate forecasting results, it is necessary to account for the significant number of indicators and their parameters that can become a potential cause of a road accident. Currently, the Road factor metrics, characterized by road infrastructure indicators, are the least studied.

In the field of road construction, road operation and reconstruction, it is necessary to take into account the system of parametric characteristics of road facilities and conditions for their existence: the geometry of road environment facilities (GREF); transport and operating conditions (TrOC); technical and operating conditions (TechOC); the state of road infrastructure facilities (SRIF).

The parametric characteristics of road facilities and conditions were evaluated in the Road - Accident Cluster - Forecast system. Due to the detection and analysis of accident clusters, it became possible to obtain absolute and relative values for the number of road accidents, perform system analysis for each accident cluster. It is suggested to determine GREF, TrOC, TechOC, SRIF values at an accident cluster, using a system of road infrastructure indicators obtained based on parametric data on the passportization of roads, instrumental evaluation and diagnostics of changes in their actual state.

Table 2 suggests road infrastructure indicators for the system analysis of accident clusters.

Due to the analysis of accident clusters using road infrastructure indicators, it is possible to solve the following tasks:

- to evaluate traffic safety on a road operated, as well as the accident rate and its change trends;

- to reduce the number of road accidents and their severity;

- to improve transport and operating characteristics of a road;

- to identify accident clusters;

- to bring infrastructure development elements and traffic management equipment in line with applicable regulations.

Table 2. Road infrastructure indicators for the system analysis of accident clusters

\begin{tabular}{|c|c|}
\hline $\begin{array}{l}\text { Road infrastructure indicator to be } \\
\text { analyzed }\end{array}$ & $\begin{array}{c}\text { Description } \\
\text { of the road infrastructure indicator } \\
\text { to be analyzed }\end{array}$ \\
\hline \multicolumn{2}{|r|}{ Geometry of road environment facilities } \\
\hline$N i$ & Number of traffic lanes \\
\hline$W_{\text {pull }}$ & Width of the pullover, $\mathrm{m}$ \\
\hline$W_{\text {div str. }}^{\text {centr }}$ & Width of the central dividing strip, $m$ \\
\hline$W_{m \text { arg }}^{s h}$ & Width of the margin strip, $m$ \\
\hline$S_{\text {marg }}^{s h}$ & Width of the margin strip, $m$ (state of the margin strip) \\
\hline$L_{\text {stop }}$ & Width of the stopping lane, $\mathrm{m}$ \\
\hline$i$ & Longitudinal grade, per mille \\
\hline$i_{\text {trans }}$ & Transverse grade, per mille \\
\hline$i_{r}$ & Raised curve grade, per mille \\
\hline
\end{tabular}




\begin{tabular}{|c|c|c|}
\hline \multirow{29}{*}{ 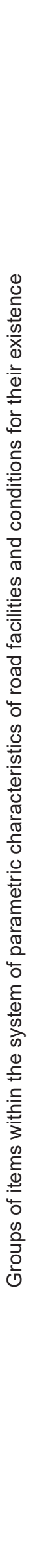 } & $R_{\text {curve }}$ & Curve radii in plan, $\mathrm{m}$ \\
\hline & $S_{c l}$ & Clear vision distance to the object, $\mathrm{m}$ \\
\hline & $R_{\text {convex }}$ & Radii of convex curves in profile, $m$ \\
\hline & $R_{\text {concave }}$ & Radii of concave curves in profile, $m$ \\
\hline & $h_{f}$ & Depth of fill, $m$ \\
\hline & $h_{e}$ & Depth of excavations, $\mathrm{m}$ \\
\hline & $\angle_{\text {slope }}$ & Slope grade \\
\hline & & Transport and operating conditions \\
\hline & $I_{v e h}$ & Traffic intensity, vehicles/day \\
\hline & $V_{v e h}$ & Allowable vehicle speed, $\mathrm{km} / \mathrm{h}$ \\
\hline & $G_{v e h}$ & Allowable axial load, $\mathrm{t}$ \\
\hline & $K_{p}^{I-V}$ & Braking performance coefficient for ground vehicles \\
\hline & $N_{A C C}$ & Number of road accidents \\
\hline & $A C C_{a b s}$ & Absolute accident rate indicator \\
\hline & $A C C_{r e l}$ & Relative accident rate indicator \\
\hline & $C_{v e h}$ & $\begin{array}{l}\text { Vehicle categories according to the classification of the UN Eurasian Economic } \\
\text { Commission }\end{array}$ \\
\hline & & Technical and operating conditions \\
\hline & $\phi$ & Road/tire adhesion coefficient \\
\hline & $t$ & Depth of the road track (wheel tracking), $m$ \\
\hline & $r$ & Roughness of the road surface, average height of material projection, $10-6 \mathrm{~m}$ \\
\hline & E & Modulus of elasticity of the road surface, MPa \\
\hline & $D_{r . s .}$ & Parameters of road surface defects \\
\hline & & State of road infrastructure facilities \\
\hline & $T_{a . s .}$ & Artificial structures \\
\hline & $T_{\text {drain }}$ & Drainage systems \\
\hline & $T_{k m}^{p o s t}$ & Kilometer posts \\
\hline & $T_{\text {light }}$ & Lighting \\
\hline & $T_{\text {rail }}$ & Railway crossings \\
\hline & $T M E$ & Traffic management equipment \\
\hline
\end{tabular}


- to elaborate effective management decisions as well as measures for the elimination of black spots (current and forward-looking measures) and high-priority measures for the prevention of black spot formation (current and forward-looking measures);
- to evaluate changes in the accident rate indicators as a result of implementing measures to improve traffic safety.

Figure 3 shows an algorithm of analyzing road infrastructure at accident clusters with the use of the indicators.

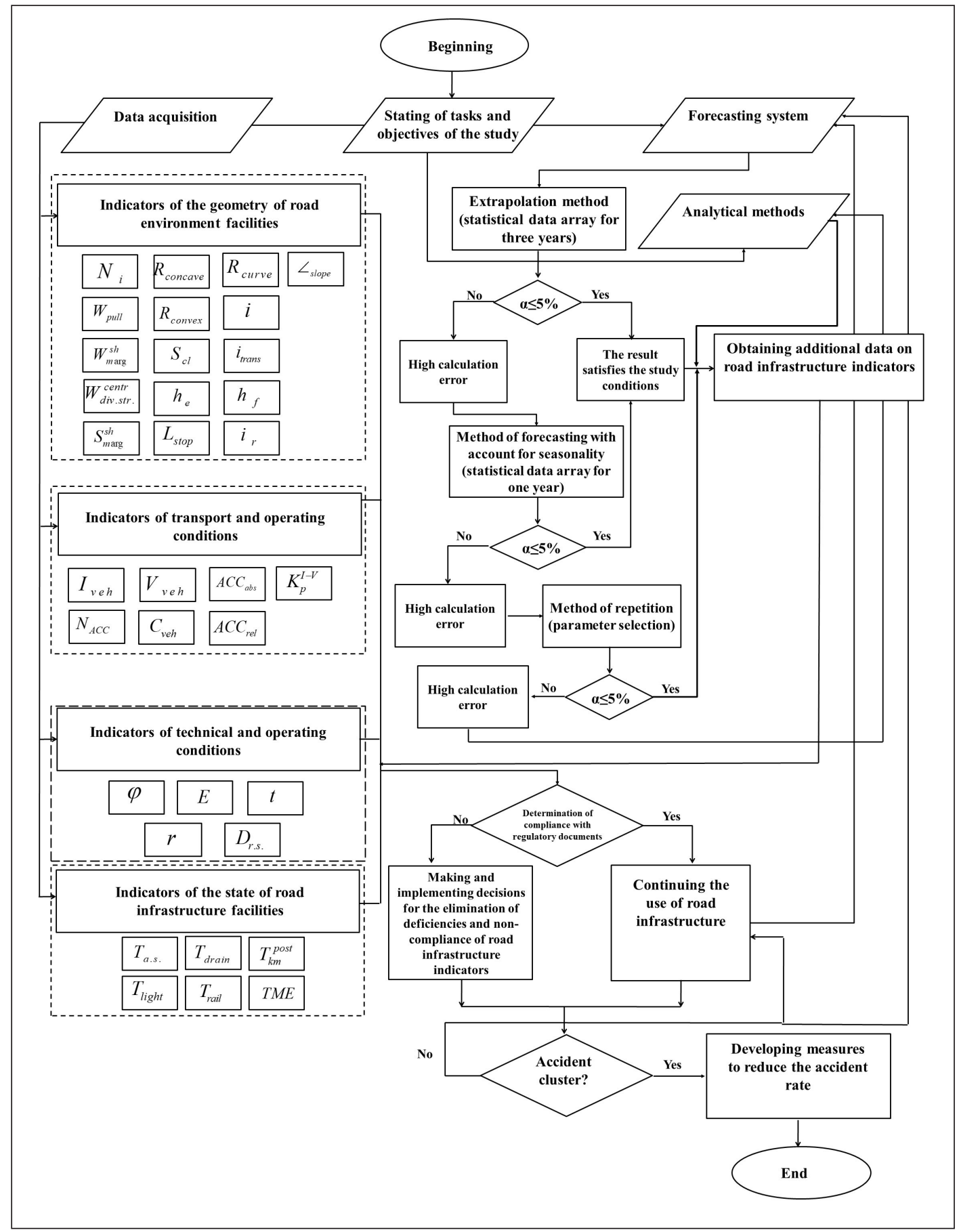

Figure 3. Algorithm of road infrastructure analysis at accident clusters

\section{Conclusions}

Based on the analysis of statistical data on the road accident rate, the systemic indicators of road infrastructure were determined. Due to the use of the system of road infrastructure indicators, it will be possible to ensure traffic safety both at the stage of road design and construction and at the stage of road operation. 


\section{References}

Brannolte, U., Silyanov, V., Chubukov, A., Kapitanov, V. and Monina, O. (2017). Simulation of regional mortality rate in road accidents. Transportation Research Procedia, Vol. 20, pp. 112-124. DOI: 10.1016/j.trpro.2017.01.031.

Domke, E. R. and Zhestkova, S. A. (2011). Probabilistic model brakes wheeled vehicles. The World of Transport and Technological Machinery, 2, pp. 3-7.

Evtiukov, S., Kurakina, E., Lukinskiy, V. and Ushakov, A. (2017). Methods of accident reconstruction and investigation given the parameters of vehicle condition and road environment. Transportation Research Procedia, Vol. 20, pp. 185-192. DOI: 10.1016/j. trpro.2017.01.049

Evtyukov, S. A. and Vasiliev, Ya. V. (2008). Road accidents: investigation, reconstruction, expert examination. Saint Petersburg: Publishing House DNK, 392 p.

Federal Road Agency (Rosavtodor) (2015). Recommendations for accounting and analysis of road accidents on the roads of the Russian Federation. Industrial Road Guidance Document ODM 218.6.015-2015. Moscow: Federal Road Agency (Rosavtodor), 78 p.

Ilarionov, V. A. (1989). Expert examination of road accidents. Moscow: Transport, 255 p.

Kapitanov, V., Silyanov, V., Monina, O. and Chubukov, A. (2018). Methods for traffic management efficiency improvement in cities. Transportation Research Procedia, Vol. 36, pp. 252-259. DOI: 10.1016/j.trpro.2018.12.077.

Kravchenko, P. A. (2013). Traffic safety and management in large cities. Science and Engineering for Roads, 1, pp. 1-2.

Kravchenko, P. and Oleshchenko, E. (2017). Mechanisms of functional properties formation of traffic safety systems. Transportation Research Procedia, Vol. 20, pp. 367-372. DOI: 10.1016/j.trpro.2017.01.051.

Kurakina, E. V. (2018). On the effectiveness of studies carried out at places of road traffic accident concentration. Bulletin of Civil Engineers, 2, pp. 231-237. DOI: 10.23968/1999-5571-2018-15-2-231-237.

Kurakina, E. V., Evtyukov, S. S. and Golov, E. V. (2017). Reconstruction of road accidents. Saint Petersburg: Petropolis Publishing House, $204 \mathrm{p}$.

Kurakina, E., Evtiukov, S. and Rajczyk, J. (2018). Forecasting of road accident in the DVRE system. Transportation Research Procedia, Vol. 36, pp. 380-385. DOI: 10.1016/j.trpro.2018.12.111.

Plotnikov, A. M. (2016). A method of ensuring traffic safety at controlled intersections in megacity street and road networks. DSc Thesis in Engineering. Saint Petersburg: Saint Petersburg State University of Architecture and Civil Engineering.

Rajczyk, P., Kurakina, E. and Knapiński, M. (2018). The influence of surface topography on the safety of road and utility surfaces. Transportation Research Procedia, Vol. 36, pp. 640-648. DOI: 10.1016/j.trpro.2018.12.139.

Suvorov, Yu. B., Kikot, I. M., Khapatnyukovsky, M. V., Kovalenko, L. A. and Kilienko, I. I. (1990). Diagnostic study of road elements at sections of high accident rate (road conditions) affecting road safety. Guide for experts, investigators and judges. Moscow: All-Union Research Institute of Forensic Analysis, $93 \mathrm{p}$.

Vrubel, Yu. A., Kapsky, D. V., Kot, Ye. N. (2006). Determination of losses in road traffic. Minsk: Belarusian National Technical University, $252 \mathrm{p}$. 


\title{
СИСТЕМООБРАЗУЮЩИЕ ИНДИКАТОРЫ ДОРОЖНОЙ ИНФРАСТРУКТУРЫ В МЕСТАХ КОНЦЕНТРАЦИИ ДТП
}

\author{
Елена Владимировна Куракина', Сергей Аркадьевич Евтюков², Григорий Гинзбург ${ }^{3}$ \\ 1,2Санкт-Петербургский государственный архитектурно-строительный университет \\ 2-ая Красноармейская ул., 4, Санкт-Петербург, Россия
}

${ }^{3}$ Вице-президент Международной ассоциации реконструкции и экспертизы ДТП Соединённые Штаты Америки

1E-mail: elvl_86@mail.ru

\section{Аннотация}

Для исследования дорожной инфраструктуры и контроля за ее изменением в период эксплуатации возникает необходимость введения понятия «индикатор», представляющий собой параметр или характеристику состояния объектов дорожной инфраструктуры. Исследование индикаторов дорожной инфраструктуры направлено на повышение безопасности дорожного движения, совершенствование системы прогнозирования дорожно-транспортных происшествий (ДТП). Реализовано применение системы учета характеристик объектов дорожной инфраструктуры, закладываемых при проектировании и строительстве автомобильных дорог, в интересах прогнозирования ДТП. Цель исследования. Разработка подхода к исследованию влияния системообразующих индикаторов дорожной инфраструктуры в местах концентрации ДТП на безопасность дорожного движения. Методы. Системный анализ, метод экстраполяции, метод прогнозирования с учетом сезонности, метод повторяемости. Результаты. Выполнен анализ статистических данных аварийности на автомобильных дорогах и выявлены значимые системообразующие индикаторы дорожной инфраструктуры с целью оценки эффективности мероприятий дорожно-строительной сферы в обеспечении безопасности дорожного движения (ОБДД). Сформированы группы показателей в системе их параметрических характеристик и определены условия их использования для исследования системообразующих индикаторов дорожной инфраструктуры. Определены возможности методов прогнозирования дорожной аварийности для разработки алгоритма исследования дорожной инфраструктуры в местах концентрации ДТП. Разработан алгоритм исследования дорожной инфраструктуры в местах концентрации ДТП.

\section{Ключевые слова}

Автомобильная дорога, индикатор, дорожное покрытие, транспортное средство, дорожно-транспортные происшествия, место концентрации ДТП. 